\title{
DESIGN AND DEVELOPMENT OF FAST CHARGING BATTERY USING FUZZY LOGIC CONTROL TECHNIQUE
}

\author{
$1^{\text {st }}$ Naji Abdalaziz Ali \\ Student of Post Graduate Program of Mechanical Engineering \\ Sebelas Maret University \\ Surakarta, Indonesia \\ zizoali1990@gmail.com
}

\author{
$2^{\text {nd }}$ Muhammad Nizam \\ Department of Electrical Engineering \\ Sebelas Maret University \\ Surakarta, Indonesia \\ muhammad.nizam@staff.uns.ac.id
}

\begin{abstract}
Battery charging is an important issue when it is associated with battery life and cycle performance. The aim of this research is to design and promote fast battery chargers using fuzzy logic control techniques (FLC) for LiFePO4 batteries have been developed. The proposed charger is controlled by voltage and current to activate the PWM duty. The results show that the proposed battery charger has the potential to accelerate charging up to $37 \%$ at the rate when charging $2 \mathrm{C}$. This means it is faster than the existing filling. The charger proposed by the FLC method is also capable of charging $\mathrm{LiFePO} 4$ batteries with greater efficiency, which is $82 \%$. It can be concluded that the FLC application method has better performance than the $\mathrm{CC}-\mathrm{CV}$ method.
\end{abstract}

Keywords-Electric Vehicle (EV), Fuzzy Logic Controller, $\mathrm{LiFePO4,} \mathrm{PWM}$

\section{INTRODUCTION}

Over the past several decades, the technology of rechargeable batteries has increased as a consequence of the rapid advances in portable devices such as smartphones, MP3 players, and wireless power tools. During the charging process, electrons flow from negative to positive as opposed to the flow in the charge release time. It requires a charger that matches the type of battery available [1]

The charging method commonly adopted for $\mathrm{Li}$-ion batteries is the constant current constant voltage $(\mathrm{CC}-\mathrm{CV})$ method. For the CC-CV method, a large constant current is applied at the beginning of the charging cycle when the battery charging status (SOC) is low. When the battery voltage rises to a predetermined limit, the charger switches to a constant voltage charging mode and continues in that mode until the charging current decreases to a predetermined small value. Although $\mathrm{CC}-\mathrm{CV}$ is simple to implement, it is not suitable for fast charging. That's because charging $\mathrm{CV}$ can extend overall charging time and also reduce battery life [2].

Many advanced battery charging techniques are proposed. In [3, 4] PLL-based battery chargers (PLBC) are introduced. Based on PLBC, the optimal pulse frequency and optimal duty cycle can then be determined using sweeping methods to improve PLBC performance $[5,6]$. Besides, the effect of internal resistance on the open-circuit voltage is also calculated [6] to increase the charging speed of the PLBC. Chen et al. [7] have a sinusoidal-ripple current charging strategy; this approach can minimize battery impedance and consequently maximize energy transfer efficiency. The reason for using pulse charging and sinusoidal current charging techniques is to get smaller pulse charging than those obtained by $\mathrm{CC}$ charging. However, this method requires specialized hardware to produce pulsed or sinusoidal charging currents. Besides, this method is not truly "adaptive" because additional "search mode" must be used to determine the optimal pulse frequency/duty cycle value [5, 6]. Another method that can be used to reduce charging time is to adjust the charging current to the battery status using a smart controller. In $[4,8]$, the intelligent controller is applied by changing the $\mathrm{CV}$ mode and the $\mathrm{CC}-\mathrm{CV}$ charging method.

A common problem with chargers is the length of time a fast charging can be obtained by utilizing different charging conditions. Excessive charging time can damage the battery. Therefore, this research aims to design and implement a fast battery charger based on a fuzzy logic controller.

\section{THEORY}

\section{A. Selecting Basic Concept of rechargeable Li Ion Battery}

A lithium-ion rechargeable battery is a type of highperformance battery that works based on the movement of ions between the cathode and anode. Ions are intercalated from the anode and interspersed with the cathode during charging and vice versa for use. Throughout the evolution of batteries, lithium- ion batteries are better than other battery cells because of their portable, environmentally friendly, high energy density, and long cycle life features. Among commercial batteries, lithium-ion batteries have the lightest metals compared to other type of batteries. It also has the most significant specific energy per weight and specific energy per volume [9].

\section{B. Specification of LiFePO4 cell (LR1865AM)}

$\mathrm{LiFePO} 4$ cell is a cell type that has a maximum capacity of 1.1 to $1.4 \mathrm{Ah}$; the standard voltage is different from another cell type, which is 3.2 volt. It means that the discharge condition of $1 \mathrm{C}$ would reach 3.2 volts until the battery power drops and battery voltage decreases accordingly with the current. LiFePO4 cell has cut off voltage of 2 volts. Maximum current discharge is 20C - 25C (in the 30s) which means an average of $21-27.5 \mathrm{~A}$ in 30 seconds. However, it will not discharge all power cell capacity because it saturates and resting time is needed to be able to release rest power. Rest power capacity can be discharge on the constant current at $0.5 \mathrm{C}$. 
Constant current mode (CC) is needed for started initializing and continuous voltage mode $(\mathrm{CV})$ to charge the cell. The voltage reaches a maximum voltage of 3.6 volt and current drops under $20 \mathrm{~mA}$. Current charge decreases on the $\mathrm{CV}$ mode; it consequently needs a longer time to transfer energy into the cell. When CC mode constrained up to full capacity, overvoltage will happen, and it probably happens heat loss and decrease cell power transfer efficiency. The standard current charge of $\mathrm{LiFePO} 4$ cell is $0.5 \mathrm{C}$, and its maximum is $2 \mathrm{C}$ continually and $3 \mathrm{C}$ periodically. The living cell is from 2500-3500 cycles in average condition. It means that the cell can charge and discharge 2500-3500 times. The permitted temperature undercharging is under $60^{\circ} \mathrm{C}$, and it is not advisable to charge the battery on temperature under $0^{\circ} \mathrm{C}$.

The standard voltage of 3 cells for this research is 9.6 Volt (3.2x3), and the maximum voltage is 10.8 Volt $(3.6 \times 3)$. For multiple cells that charged with single-source power, there are possibilities of cell unbalance occurrence in a level of charging. If a cell reaches full charge and another cell not then charging process will stop. This process would do to avoid damage to the module or at pack battery.

\section{Fuzzy Logic System}

Lotfi Zadeh, the father of fuzzy logic, claimed that many sites in the worlds are defined by a non-distinct boundary. Zadeh decided to extend two-value logic, represented by the binary pair $\{0,1\}$, to the whole continuous interval $[0,1]$, thereby introducing a gradual transition from falsehood to truth. Fuzzy control is a control method based on fuzzy logic. Fuzzy logic can be described merely as "computing with words rather than numbers"; fuzzy control can be described merely as "control with sentences rather than equations." A fuzzy controller can include empirical rules that are mainly useful in operator-controlled plants.

Even though the broad sense of fuzzy logic covers a wide range of theories and techniques, its core technology is based on four fundamental concepts:

1. Fuzzy sets: sets with smooth boundaries.

2. Linguistic variables: variables whose values can be described in both qualitatively and quantitatively by fuzzy sets.

3. Possibility distribution: constraints on the value of a linguistic variable imposed by assigning it a fuzzy set.

4. Fuzzy if-then rules: a knowledge representation scheme for describing a functional mapping or a logical formula that generalizes an implication in two-valued logic

\section{RESEARCH METHODOLOGY}

\section{A. Method}

The hardware configuration of charger is shown in Figure 3. Designing and developing the hardware modeling of the battery charger with controller (fuzzy logic technique) based on ATMEGA IC. IC microcontroller ATMEGA is to generate PWM with fuzzy logic. For the power supply, it is used in the main power $220 \mathrm{~V}$ and switching power supply with output $15-19$ Volt / 4A ( $\max )$.

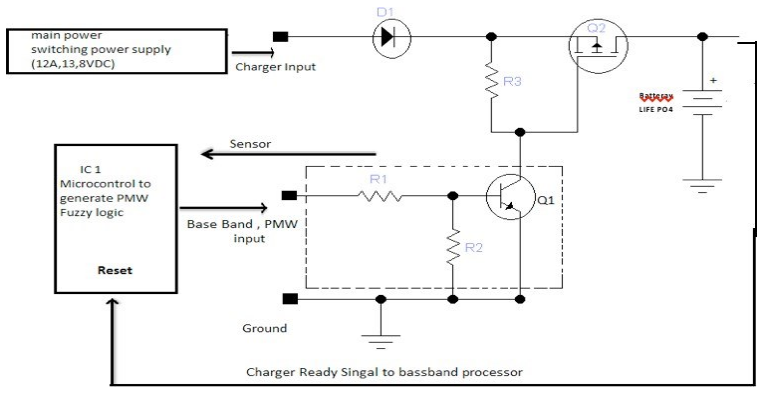

Fig. 1 Connect serial PC to record data sensor

The block diagram of this research can be shown in Figure 2.

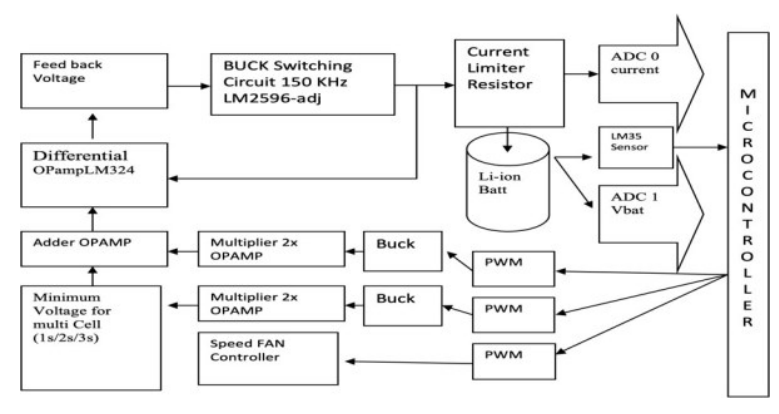

Fig. 2 Design block diagram of the system

The ATMEGA8 interrogates the fuel gauge for parameters such as charging voltage, charging current, state of charge, battery status register value, etc. The choice of parameters is governed by two factors: the desired charging power requested by the battery and any indication of error or warning condition with the battery. For a full list of parameters that can be interrogated from the fuel gauge via ATMEGA8. The ATMEGA8 outputs voltage and current PWM signals at $15 \mathrm{kHz}$ to the $\mathrm{DC} / \mathrm{DC}$ converters on the Power Stage Board. Based on the values of the desired charging voltage and charging current required, the duty cycle of the PWM signals is adjusted accordingly. Another level of protection involves taking the voltage from the battery terminals, the current from the power-stage board and level- shifting down to be sampled by the ADC on the ATMEGA8. If the voltage or current sampled by the ADC exceed a certain range, then the PWM outputs are switched off to prevent any hazard

\section{B. Instrument}

TABLE 1 INSTRUMENTS OF PRESENT STUDY

\begin{tabular}{|l|l|}
\hline Instruments & Specification \\
\hline Battery & $\begin{array}{l}\text { LiFePO4 (LR1865 AM), 3.2 volt, 1.1 } \\
\text { Ah, max } \\
\text { temperature range } 60^{\circ} \mathrm{C}, \quad 10.000 \\
12.000 \text { cycles, L:65mm and D:18mm }\end{array}$ \\
\hline $\begin{array}{l}\text { Standard charge } \\
\text { method }\end{array}$ & CC-CV \\
\hline
\end{tabular}




\begin{tabular}{|c|c|}
\hline Microcontroller & $\begin{array}{l}\text { IC ATMEGA } 8(220 \mathrm{~V} ; \text { output } 15- \\
\text { 19V/ 4A max; } \\
\text { internal oscillator } 8 \mathrm{MHz} ; 3 \text { timers } \\
\text { PWM) }\end{array}$ \\
\hline PWM & $\begin{array}{l}4 \mathrm{Khz} \text { to control fan and } 15 \mathrm{Khz} \\
\text { (OCR1A and OCR1B) } \\
\text { to control minimum level voltage } 2 \mathrm{~V} \text {, } \\
4 \mathrm{~V}, 6 \mathrm{~V})\end{array}$ \\
\hline $\begin{array}{l}\text { Buck switching } \\
\text { regulator }\end{array}$ & LM $25965 \mathrm{~V}$ \\
\hline Dual Mosfet & $\begin{array}{l}\text { CEM 3953, Optocoupler for mofset } \\
\text { driver }\end{array}$ \\
\hline Power inductor & SMD inductor $100 \mathrm{uH}, 33 \mathrm{uH}$ \\
\hline $\begin{array}{l}\text { Thoroidal } \\
\text { inductor }\end{array}$ & $\begin{array}{l}25 \text { turn with } 2 \mathrm{~mm} \text { diameter (LPF) } 10 \\
\mathrm{uH}, 100 \mathrm{uH}\end{array}$ \\
\hline Diode schotcy & IN 1522 \\
\hline $\begin{array}{l}\text { Temperature } \\
\text { sensor }\end{array}$ & LM 35 \\
\hline OPAMP & $\begin{array}{l}\text { LM2904 dual OPAMP and LM } 324 \\
\text { quad OPAMP }\end{array}$ \\
\hline Resistor & $\begin{array}{l}0.5 \mathrm{Ohm} / 10 \mathrm{Watt} \text { for limiter current } \\
\text { and current sensor } \\
5 \mathrm{Ohm} / 5 \mathrm{Watt} \text { for discharge resistor }\end{array}$ \\
\hline $\begin{array}{l}\text { Current sensor } \\
\text { and } \\
\text { voltage charge }\end{array}$ & Internal ADC Atmega 10 bits \\
\hline technology & $\begin{array}{l}\text { using FLC with switching IC LM2596 } \\
\text { amplified and } \\
\text { injected current to inductor with } 3 \text { A } \\
\text { max current }\end{array}$ \\
\hline OVP & 3.65 Volt and temperature under $40^{\circ} \mathrm{C}$ \\
\hline
\end{tabular}

\section{RESULT AND DISCUSSION}

\section{A. Time CC and CV state and OVP}

FLC increased the speed of CV state, although the experiment of charging $1 \mathrm{C}$ was faster without fuzzy than with FLC. The trial of $1 \mathrm{C}$ causes it happened decreasing capacity after discharge compared with $2 \mathrm{C}$. In other word, it stopped more quickly so that the capacity was not full. The ideal one is that smaller charging current gives higher power that charged into the cell. The view of time $\mathrm{CC}, \mathrm{CV}$, and OVP state is shown in Table 2.

\section{TABLE 2 TIME CC AND CV STATE AND OVP}

\begin{tabular}{|c|c|c|c|c|c|c|c|c|c|c|}
\hline \multirow{2}{*}{$\begin{array}{c}\text { Rate } \\
\text { charge }\end{array}$} & $\begin{array}{c}\text { CC state } \\
(\mathrm{min})\end{array}$ & \multicolumn{2}{c|}{$\begin{array}{c}\text { CV state } \\
(\mathrm{min})\end{array}$} & \multicolumn{2}{c|}{$\begin{array}{c}\text { Full charge } \\
(\mathrm{min})\end{array}$} & \multicolumn{2}{c|}{$\begin{array}{c}\text { Drop voltage } \\
(\mathrm{mV})\end{array}$} & \multicolumn{2}{c|}{$\begin{array}{c}\text { Stop charge } \\
(\mathrm{V})\end{array}$} \\
\cline { 2 - 12 } & FLC & NO & FLC & NO & FLC & NO & FLC & NO & FLC & NO \\
\hline 1C & 72 & 59 & 29 & 10 & 101 & 70 & 10.5 & 10.35 & 10.7 & 10.6 \\
\hline 2C & 14 & 23 & 27 & 43 & 41 & 66 & 10.15 & 10.2 & 10.55 & 10.7 \\
\hline $2.5 \mathrm{C}$ & 8 & 9 & 26 & 28 & 34 & 37 & 10.6 & 10.2 & 10.7 & 10.7 \\
\hline
\end{tabular}

With the system's fuzzy logic, the current increases due to faster full charging times. The $\mathrm{CC}$ state of $1 \mathrm{C}$ takes 59 minutes, and the $\mathrm{CC}$ state of $2 \mathrm{C}$ takes 23 minutes, and $2.5 \mathrm{C}$ only takes 9 minutes. That's because FLC increases OV protection. (OVP) When it reaches the standard limit, such as the voltage is below than 10.2 Volt or (3.4 volt/cell) limit, then the temperature starts to rise faster. It is due to the overvoltage, which will turn into heat loss. When the battery voltage at the voltage approaches a maximum of 3.6 volts/cell, the OVP will decrease due to the operation of the FLC to prevent an earlier current decrease and optimize the battery capacity. Furthermore, the yield current will drop rapidly until the full charge. That is why the voltage falls with FLC longer than without FLC. The cost of a trial run between $1 \mathrm{C}-2.5 \mathrm{C}$ voltage drop occurs around 10.2 volts. With $1 \mathrm{C}$ charge drop voltage to full, it takes 11 minutes, with $2 \mathrm{C}$ it takes 28 minutes, with $2.5 \mathrm{C}$ it takes 16 minutes. FLC increases the charging speed compared to without FLC, as shown in Figure 4.

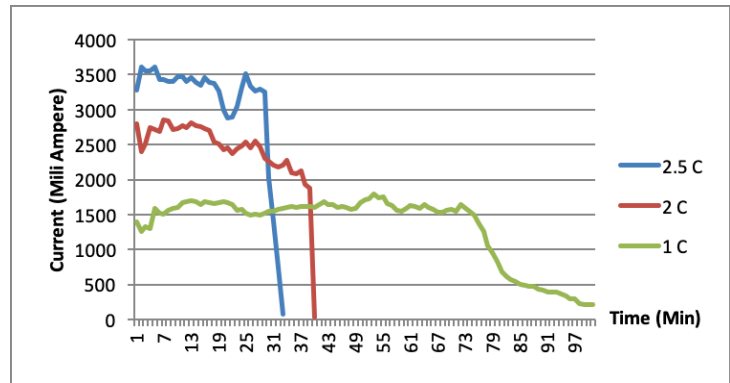

Fig. 4 Correlation of Current and Time charging with FLC

B. Efficiency of Charging

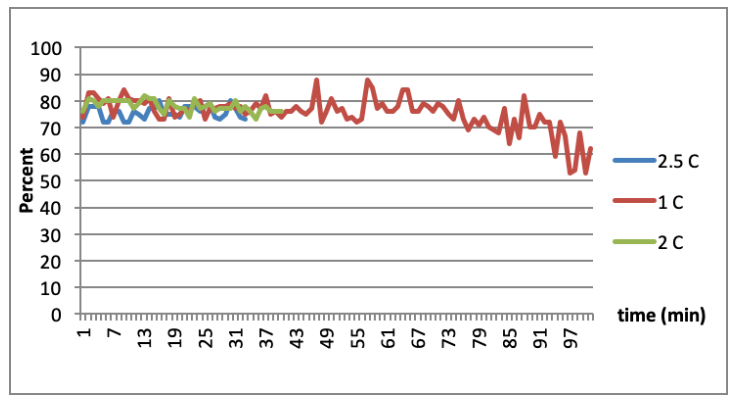


Fig. 5 Correlations of Efficiency and Time with FLC

Charge between 1-2.5 C, resulting in efficiencies between $75-85 \%$ with a pattern of decreasing efficiency when approaching the end of filling. So it can be said that charging with high currents will result in higher efficiency. However, charging with high currents will affect the temperature rise of the charged battery. So we need to adjust other variables to get high efficiency. The variables required for this are limiter resistor, FAN, module, and IC switching.

The difference between FLC and without FLC is PWM manipulation, so there is no significant difference. Efficiency (EFF) can be increased by minimizing resistor limiter, adjustable FAN speed, and minimizing module charging capacity. The total power from charging to full is in Table 3.

\section{TABLE 3 TOTAL POWER INPUT \& OUTPUT DURING CHARGING}

\begin{tabular}{|c|c|c|c|c|c|c|c|c|}
\hline \multirow{2}{*}{$\begin{array}{c}\text { Rate } \\
\text { charge }\end{array}$} & \multicolumn{2}{|c|}{$\begin{array}{c}\text { Full charge } \\
\text { (min) }\end{array}$} & \multicolumn{2}{c|}{$\begin{array}{c}\text { P input } \\
\text { (Wh) }\end{array}$} & \multicolumn{2}{c|}{$\begin{array}{c}\text { P output } \\
\text { (Wh) }\end{array}$} & \multicolumn{2}{c|}{$\begin{array}{c}\text { EFF } \\
(\%)\end{array}$} \\
\cline { 2 - 9 } & FLC & NO & FLC & NO & FLC & NO & FLC & NO \\
\hline 1C & 101 & 70 & 24,4 & 22,3 & 18,7 & 17,4 & 77 & 77 \\
\hline $2 \mathrm{C}$ & 41 & 66 & 20,7 & 26,9 & 17,1 & 20,5 & 82 & 76 \\
\hline $2.5 \mathrm{C}$ & 34 & 37 & 22,7 & 26 & 18,5 & 19,7 & 81 & 75 \\
\hline
\end{tabular}

Table 3 and Figure 6 describe clearly that FLC system has increase power charging efficiency compared without FLC on the total power that started charging up to finished. FLC increases efficiency by up to $82 \%$ on the charging of $2 \mathrm{C}$, and it was $81 \%$ compared to the previous one, that is $75 \%$ with the charging of $2.5 \mathrm{C}$. Efficiency improvement can be attained by increasing the frequency switching buck converter. It would start work at $150 \mathrm{kHz}$. The converter frequency has to decrease the R limiter and offsetting with the current sensor resolution. It also can affect reducing FAN power, minimalizing power module absorption, and further FLC optimized power charging efficiency.

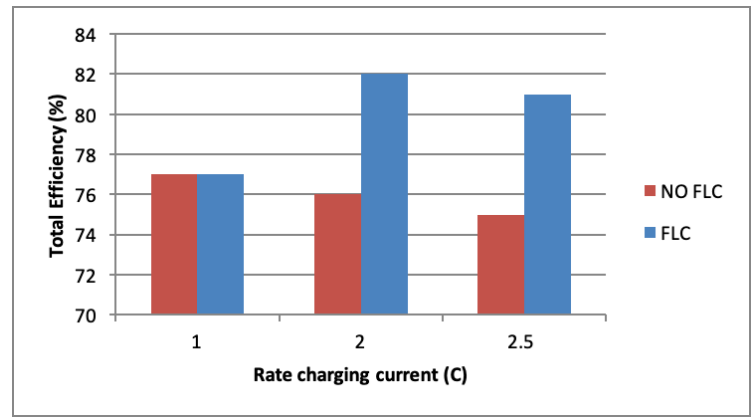

Fig. 6 Total Efficiency Charging

\section{CONCLUSION}

Experiments to get designs and develop fast chargers have been carried out using fuzzy logic control techniques on $\mathrm{LiFePO} 4$ batteries. FLC charging can speed up charging time with better efficiency and increase filling capacity. The results obtained show that the design of the proposed charger with FLC can accelerate the charging time up to $37.8 \%$ at the rate of $2 \mathrm{C}$ and produce greater efficiency, which is $82 \%$. It confirms that the application of the FLC method achieves better performance than the conventional CC-CV method. The proposed cost design is feasible to be developed and applied to design the charging device. And this proposed method, the FLC can be produced in future studies.

\section{REFERENCES}

[1] G. R. Thakur et al., DSP based Fuzzy Logic Controller For Battery Charger; ijareeie, Vol. 2, Issue 11, November 2013.

[2] Liu, C. L., Chiu, Y. S., Liu, Y. H., Ho, Y. H. and Huang, S.S., 2013. Optimization of a Fuzzy-Logic- Control-Based Five-Stage Battery Charger Using a Fuzzy-Based Taguchi Method, Energies, 6, 35283547; doi:10.3390/en6073528

[3] Chen, L.R., 2004. PLL-based battery charge circuit topology. IEEE Trans. Ind. Electron. 51, 1344- 1346.

[4] Chen, L.R.; Chen, J.J.; Chu, N.Y.; Han, G.Y., 2008. Current-pumped battery charger. IEEE Trans. Ind. Electron., 55, 2482-2488,

[5] Chen, L.R., 2007. A design of an optimal battery pulse charge system by frequency-varied technique.IEEE Trans. Ind. Electron., 54, 398405.

[6] Chen, L.R., 2009. Design of duty-varied voltage pulse charger for improving Li-ion battery- charging response. IEEE Trans. Ind. Electron., 56, 480-487.

[7] Chen, L.R.; Chen, J.J.; Ho, C.M.; Wu, S.L.; Shieh, D.T., 2013. Improvement of Li-ion battery discharging performance by pulse and sinusoidal current strategies. IEEE Trans. Ind. Electron., 60, 56205628.

[8] G.C. Hsieh, L.R. Chen and K.S. Huang, Fuzzy-controlled Li-ion battery charge system with active state-of-charge controller, IEEE Trans. Ind. Electron., 48, 585-593, 2001.

[9] Lindea, D. and Reddy, T.B. Handbook of Batteries, NewYork: McGraw-Hill, 2002, 35. 